\title{
DCLK1 Gene
}

National Cancer Institute

\section{Source}

National Cancer Institute. DCLK1 Gene. NCI Thesaurus. Code C158672.

This gene is involved in microtubule polymerization, retrograde transport and neuronal development and migration. 